\section{Benching Playground Loneliness: Exploring the Meanings of the Playground Buddy Bench}

\author{
Katherine Maureen CLARKE ${ }^{1}$
}

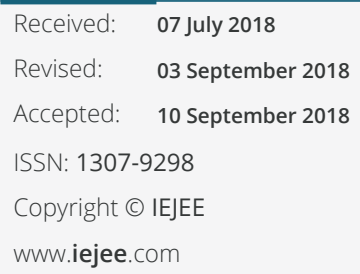

\begin{abstract}
The buddy bench, a primary school playground implementation designed to eliminate playground loneliness, provides a potential strategy to ensure more children reap the positive benefits of elementary school recess. Through children's artwork, in-depth interviews, and playground observation this ethnographic study explores the socially constructed meanings of the buddy bench and their implications. This methodology advances the communication field by demonstrating how scholars can use children's artwork to identify and define children's socially constructed meanings. Findings build on a previous study showing that playground buddy benches can offer effective playground interventions and demonstrate that the presence of a buddy bench on the playground creates shared meanings of solidarity, inherent worth, empowerment, and a shift in focus from playground bullies to buddies amongst the children. This leads to a perceived climate change on the playground. These shared meanings reshape children's narratives about themselves, loneliness, and the playground experience in a positive manner.
\end{abstract}

Keywords: Playground interventions, elementary school, social construction theory, narrative theory

\section{Introduction}

Child psychologist Kathy Hirsh-Pasek compares the call to thoughtfully educate our children to climate change, stating, "What we do with little kids today will matter in 20 years. If you don't get it right, you will have an unlivable environment" (Kamenetz, 2016). Cultivating a future filled with capable, compassionate, contributing citizens rests on today's curricular choices in primary education. Choices about free play in elementary education curricular design are particularly important as free play is a critical component in developing happy, well-adjusted individuals who have the capacity to sustain relationships and be creative, innovative, and fulfilled human beings (Brown, 2009, p. 6). Without regular opportunity to play in childhood, optimal learning, normal social functioning, self-control and other executive functions may not mature properly. Active play promotes the creation of new neural connections and stimulates brain growth in the amygdala, where emotions get processed, and the dorsolateral prefrontal cortex, where executive decisions are processed (Brown, 2009; Byers, 1998; Panksepp, 2007). Childhood play, both during the school day and at home, is a critical component in developing healthy children who grow into well-adjusted adults.

As a parent, I have a vested interest in this plight. Each day at school drop-off, I leave my children with a "go get "em" squeeze realizing my own greatest hopes and fears now pale in comparison to those I hold for my children. And, each day at pick up, the car fills with excited talk, or occasionally tears, about what happened at recess. After four years of parenting elementary school children, I have come to realize that whatever happens within my children's atmosphere on the playground sets the temperature for their day and disposition.

Knowing both the value and precarious state of play during recess in elementary school, I was intrigued when a buddy bench was introduced on the playground at the elementary school my children attend. A friendly postcard home to parents presented a picture of a park bench sitting on the playground under a colorful wooden rainbow. A Ralph Waldo Emerson quote stating, "The only way to have a friend, is to be one," scrolled in an arch under the rainbow's violet band. Text under the image of the decorated bench announced, "The buddy bench is a place where friendships begin." The card explained children who do not know who to play with at recess are invited to sit on the bench; children playing on the playground are encouraged to invite anyone sitting on the bench to play. The buddy bench was presented as "a simple solution designed to eliminate playground Ioneliness." Intrigued, I wondered, is this buddy bench going to work? And, if so, how? It is with this reflexivity that I approached this study.

Questions about the buddy bench and recess efficacy are particularly important in today's educational environment where pressure tied to school's academic performance coupled by concerns over bullying have ushered in debates about the value of recess and its role within educational curriculum. This makes this study a relevant and critical exploration. Through a qualitative case study approach, this research seeks to find what learning opportunities the buddy bench presents by exploring what children's socially constructed meanings of the buddy bench are and how these meanings influence children on the playground. 


\section{The Value of Recess in Education and Child Development}

In response to recess minutes being reallocated to academic classroom time, Ramstetter, Murray, and Gardner (2013) issued an American Academy of Pediatrics policy statement positioning recess as a vital component within school curriculum and healthy child development. The recommendation is based on vast research demonstrating the physical, mental, and social benefits of time spent on the playground (Ramstetter et al., 2013; O'Connell, 2013). After recess, children are more attentive (Jarrett et al., 1998; Stellino \& Sinclair, 2008), better behaved and more productive (Bjorklund \& Brown, 1998; Pellegrini \& Bohen, 2005), and have improved cognitive performance (Pellegrini \& Bohen, 2005; Pellegrini et al., 1995; Reed et al., 2010).

In addition to revitalizing students and enhancing classroom learning, recess offers its own unique learning opportunities. Play is widely recognized as a pillar in healthy child development (Barros, Silver \& Stein, 2009). Recess offers children the opportunity to develop friendship skills (Kocan, 2012, p. 315) as free play is critical in developing constructs about the self and others (Pellegrini et al., 2004; Ramstetter, 2013; Rönnlund, 2013; Skelton \& Francis, 2003). Play gives children the opportunity to learn and practice communication skills including collaboration, negotiation, cooperation, sharing, conflict-resolution, and problem solving (Ginsburg, 2007; Pelligrini \& Galda, 1993; Ramstetter et al., 2013). Playing freely with peers fosters children's desire and ability to see things from another's perspective (Ashiabi, 2007). The development of these interpersonal skills leads to enhanced self-confidence, selfadvocacy and resiliency (Blasi et al., 2002; Erikson, 1985). Free choice during free play enhances children's decisionmaking skills and helps children discover their own areas of interest leading them to develop individual passions they wish to pursue (Blasi et al., 2002; Erikson, 1985). Play is joyful and leads to enhanced creativity (Herrera, 2012). Recess also offers children the healthy opportunity to be outside and move freely (Pelligrini, 2008).

Free play in early childhood offers vital learning opportunities for all children, including special needs children and children with individual needs (Pistav \& Kayhan, 2017). Pediatrician Robert Murray believes playground lessons are equally important to classroom lessons. Murray stated, "There is a lot more going on (at recess) than initially meets the eye. Children are developing many, many skills during recess that will assist them for a lifetime" (O'Connell, 2013).

\section{The Hot Lava at Recess}

Yet, recess is not all fun and games. While the playground is ripe with learning opportunities, it is also rife with struggle. Some educators regard recess negatively citing it as, "the main source of conflict and difficulties" (Arthur, 2004, p. 6). Research shows the majority of school bullying happens on the playground (Pellegrini \& Long, 2002). Interpersonal conflict at recess can feel isolating and even devastating for children (Cullingford, 1995, p. 81). Recess hazards can negate the potential positive benefits of recess and even the entire educational experience. A negative playground event can contribute to low self-esteem both in and out of school. This can have an adverse effect on the child's ability to learn (Cullingford, 1995; Thompson, O'Neill, \& Cohen, 2001, p. 217).

Examining the elements shaping the playground experience enables informed design decisions. This better ensures each child's opportunity to reap the benefits of free play at recess. Research detailing both the positive and negative opportunities within recess exists. Yet, research showing how the buddy bench shapes children's playground experiences for better, or worse, if at all is limited. The only other study about the buddy bench found the buddy bench "shows promise as a relatively simple strategy to improve the school recess environment" (Griffin, Calderella, Sabey \& Heath, 2017, p. 35). That study, conducted at an inner-city urban school, called for more studies at various types of schools. This study aims to meet that call.

\section{Social Construction Theory}

This study's exploration of the buddy bench meanings rests upon Berger and Luckmann's 1966 exploration of knowledge as a social construction. Berger and Luckmann's seminal work embodies the post-positivist mindset positioning knowledge and understanding as an always developing, perpetually incomplete, and unresolved entity consisting of generated subjective interpretations that build upon each other. Upon Berger and Luckmann's foundational concept of knowledge as a social construction, semiotics, the study of how socially constructed meaning is created and perpetuated through signs, provides a lens to explore the buddy bench and discover the meaning of the buddy bench within children's interpretations.

\section{Semiotic Theory}

Semiotic theory holds a sign is established through the convergence of an abstract concept and the concrete form (Batu, 2012, p 465). Based on the construct that meanings reside within people rather than in words or objects, Peirce (1965) asserts everything can be a sign, as long as it has the ability to represent something according to the individual's interpretations and thoughts. This study seeks to apply semiotic theory by explaining what the signifier, the bench, signifies by identifying the children's interpretations. Barthes (1964) postulates no sign exists on its own, so it is important that the children's meanings of the buddy bench be contextualized within the system of recess, education, and child development.

\section{Narrative Paradigm Theory}

To answer research question number two and understand how the meanings of the buddy bench influence children on the playground, this study utilizes Fisher's (1984) narrative paradigm theory which purports that we make sense of ourselves, others, our communities, and our world through the constantly evolving and highly subjective stories we craft and tell ourselves, and others, about our experiences (Fisher, 1984, p.55). Our ability to make sense of, and create meaning from, our stories forms our "truth about the human experience" (Fisher, 1984, p. 6). Building on Fisher's idea that our identity is based upon the stories we tell ourselves, "narrative identity" refers to the internalized story an individual creates and tells themselves (McAdams, Reynolds, Lewis, Patten, \& Bowman, 2001). Themes of an individual's narrative identity not only shape a person's selfperception, but also guide and can predict an individual's behaviors (McAdams \& Guo, 2015). For example, people who tell redemptive stories, where their identity and experiences are defined by growth, communion, and agency, are more likely to believe their lives are meaningful and are driven to contribute to society in positive ways. Conversely, people who tell "contamination stories," where their stories about their lives are defined by turning points that pivot their lives from "good" to "bad," have higher levels of anxiety, depression, and harbor less fulfilling perceptions of their overall life experience (McAdams et al, 2001). These findings were re-tested and confirmed by Alder et al. (2015) who found that unlike contamination stories, redemptive stories that reflect the storyteller's feeling of control over their lives, feelings of connection to others, and feeling a sense of progress as their lives 
advance, have a more positive identity that leads to more prosocial behaviors (McAdams et al 2015). Grant and Dutton (2012) confirmed these findings with studies showing people who cultivate empowering personal narratives develop positive self-perceptions and are more likely to be more generous toward others and give their time and energy toward causes "bigger than themselves."

Based on the themes present in the children's narratives about the playground and the buddy bench, we can identify how, if at all, the presence of the buddy bench on the playground influences the children.

\section{Buddy Bench Efficacy}

Recognizing that recess offers valuable learning opportunities, but that these opportunities can be waylaid by social emotional issues, social interventions have been implemented at various schools. It is important that the efficacy of these interventions be evaluated to ensure the desired results are being achieved. Since 2013, thousands of buddy benches have been installed on elementary school playgrounds all around the world (Botev \& Dimov, 2018). Yet, we have very little research about the implications of the buddy bench, what the presence of the bench on the playground means to elementary school children, and how these meanings influence the children's perceptions about themselves, others, and play at recess. Therefore, this study seeks to find:

\section{RQ1: What is the socially constructed meaning of the playground buddy bench for children?}

RQ2: How, if at all, do the buddy bench meanings influence children on the playground?

Situating these questions in current recess and educational literature, and with application of relevant theoretical lenses, helped to contextualize and guide this inquiry.

\section{Method}

\section{Ethnographic Case Study}

The research paradigm that best fits in determining the children's socially constructed meanings, and identifying the themes in the narratives related to these meanings, is a qualitative ethnographic case study. Ethnography's aim is to understand everyday meanings in life through an insider perspective (Geertz, 1973, p. 16). This method's goal matches this study's goal which is to explore the meaning of the buddy bench through the perspectives of the children it is designed to serve. Ethnography's approach in obtaining a holistic picture and understanding of individual's everyday experiences (Fraenkel \& Wallen, 1990) via observation coupled by in-depth interviews with individuals and relevant others (Jacob, 1987) meets semiotic theory's call for identifying individual perceptions situated within systemic context. I chose a case study in accordance to Merriam's (1998) assertion that a study focused on school culture and student behavior should employ an ethnographic case study format (p. 14).

\section{Case Study Site Selection}

Located in the heart of a western mountain valley usually selected for cowboy movie backdrops, dude ranch vacations, and retirees' ranches, Coeur D'Valle Primary School recently instituted a playground buddy bench and offers an optimal site for a buddy bench case study. With a student body of almost 500 students, grades kindergarten through fourth grade, Coeur D'Valle is both representative of an American public school today, and reflective of the town's spirit of independence, close-knit community, and small town values.
Like most public schools, Coeur D'Valle Primary strives and struggles to meet national standards with limited and diminishing resources. In spite of the challenge, the school has remained steadfast in its commitment to "Children First." Principal Jane Steward is most proud of "Our community, this place is overflowing with people so truly kind and hard-working, they make me proud to be a human" (personal communication, June 8, 2016).

Accordingly, the school introduced the playground buddy bench with august attention given to the bench's presentation and inception. Winnie Schultz, the school's most requested teacher and recipient of the state's highest award for teaching excellence, took the lead in bringing a buddy bench to Coeur D'Valle. Winnie says, "If it's a good idea, and it benefits kids, I'll make it happen" (personal communication, June 15,2016$)$. And so, she did. The Coeur D'Valle Primary School buddy bench debuted on the playground in late February of 2016 . Three months into its playground tenure, the novelty of the buddy bench had worn off, the bench had established patterns of usage, and children's stories and experiences had begun to shape their understandings of the buddy bench. This made the end of the school year an ideal time for investigation.

\section{Drawing Thick Description with Children}

Geertz (1973) asserts understanding the meanings individuals hold relies on the ethnographer's ability to cultivate "thick description" based upon interview and observation data. Obtaining "thick description" from children via traditional verbal interviews is challenging because, "verbal and social skills are still in the early stages of development" (McNiff, 1976, p. 115). Interviewing children seemed neither developmentally appropriate nor promising, so I coupled 15 hours of playground observation with interviews of relevant others (primary school staff, faculty, and parents) and analysis of children's "before and after the buddy bench" artwork.

The parent interviews doubled as play-dates between my children and the interview subject's children. I wanted the interviewee's children to be able to come in and out of the conversation as they wished. Over the months of June and July interview play-dates occurred after school in familiar settings including the school playground, community park, and on our backyard decks while our children played in the yard. An interview guide (see Appendix) was loosely followed allowing for participants to expound upon stories their children told them, and elaborate on their interpretations of their children's experiences.

To achieve understanding directly from the students' perspective, I followed "crayon man," child psychologist Robert Coles's, method of learning about children's meanings through their artwork. In an interview with McNiff (1976), Coles says children's artwork communicates what children experience while, "words often fail to do justice to the actual landscape of their minds" (p. 117). Like his art-therapist colleagues, Coles believes drawing offers children a way to communicate that is comfortable, active, and natural (p. 122). Because an artist's art "comes from their perception of the world" (p. 126), Coles articulates art therapists' belief that through a child's drawings, the artist "reveals their attitudes toward themselves" (p. 128), and we can see how children experience the world (p. 123).

Modeling Coles's methodology, I asked the parents । interviewed to have their children complete an art prompt (See Appendix) prior to our interview. The art prompt guided children to create two pictures of the playground: one picture of the playground without the buddy bench, and one picture of the playground with the buddy bench. An important part of the art prompt was the parent asking the child to "Tell me about your drawings" after the child 
was finished creating it. Art therapists use this specific phrase, as opposed to "What is it?" because it offers the artist an open-ended opportunity to share his or her artistic creation without judgment (Di Leo, 2015, p. 5).

To be respectful of children's limited verbal capacity and comfort in an interview-type situation, my plan was to invite the parent to relay what the drawing communicated about their child's experiences. However, often children arrived at the interview play-date proudly presenting their drawings. The children were eager to tell me all about their pictures without any prompting or help from me or their parents.

My interpretations of the children's artwork were modeled after Coles who took the child's explanation into account while also noting object's sizes and spacing (McNiff, 1976, p. 128 ), tone and colors, or lack of (p. 128), facial expressions, or lack of (p. 128), and landscape (p. 127). Coles's analysis methods are aligned with many clinicians who use children's art as a diagnostic tool in psychology and psychiatry practices. Di Leo (2015) and Oster and Crone (2004) expound upon the categories Coles mentioned linking specific graphic elements with specific meaning.

Related to object size and spacing, the relative size of figures can denote the child's perceived importance and power of the subject. Figures that are relatively larger indicate a more dominant subject, and objects that are relatively smaller indicate a less powerful or significant perception of the subject. Di Leo (2015) writes, "Insecure children tend to draw themselves as a small person in contrast to the large, boldly-drawn figure typical of secure children" (p. 66). The complete absence of a figure, or the absence of an aspect of that figure, such as missing hands or missing facial expressions, indicate passivity and a lack of power (Di Leo, p. 19). In addition to figures relative sizes, spacing can also be indicative of a child's perceived sense of power. Figures that are centered can indicate strength and security. Figures that are drawn in the corners, on the edges, or at the bottom of the drawing can be an expression of feelings of inadequacy or insecurity (Di Leo, p. 14; Oster \& Crone, p. 121).

Tone and colors, or lack of, can indicate the artist's mood. Oster and Crone write, "Characteristics of depressive symptoms in drawings might be lessened colors or dark colors" (p. 24). Conversely, bright colors can indicate vitality and cheer (Di Leo, p. 209). Coles notes that children's moods are often represented by the colors they use and the weather they portray. Bright sunshine can indicate cheer and joy while gray, rain, and snow can indicate the child's discomfort (McNiff, 1976).

These graphic elements in children's artwork can be linked to certain meanings, yet the analysis needs to fit within the themes of the drawings themselves and must be taken within context of what the child articulates, and what the researcher observes. Coles warns, "You cannot look at children under a microscope. You must rather observe them in relation to the totality of the particular environment and social context in which they live" (p. 116). Based on this directive, I placed the children's drawings and interpretations in context by cross-referencing this data with the children's stories relayed to me by their parents, interviews with primary school staff and faculty, and my own playground and school observations. From these interactions, data was generated allowing for a content analysis of the drawings which revealed key themes.

\section{Participants}

Participant selection for parent interviews was based on purposeful sampling. I interviewed eleven informationrich parents who spoke on behalf of sixteen children representing each primary school grade. Highly involved parents were selected because of their ability to represent the experiences of their own children within an informed context of the school's culture, the community, and the buddy bench's presentation and usage. Based on data theoretical saturation principle, I determined my sampling was complete when new ideas were no longer being presented (Bowen, 2008).

\section{IRB Approval}

Because this study involved human subjects, IRB (Institutional Review Board) approval was needed prior to the study's inception. After the study's aim and procedure had been explained by the lead researcher, the school district superintendent, building principal, participating teachers and staff, and parents of participating children all consented by signing written informed-consent forms. Anonymity of both the school district and the participating parents, students, and school staff members were all guaranteed conditions of participation. Anonymity is important because children's social and emotional development is very personal. Therefore, any identifying information, including the names of all parties involved in the study, and the name of the school and district, have been changed within this report.

\begin{tabular}{cccc}
\hline $\begin{array}{c}\text { Interview Participant } \\
\text { (Parent)* }\end{array}$ & $\begin{array}{c}\text { Parent's school involve- } \\
\text { ment }\end{array}$ & $\begin{array}{c}\text { Name, Grade Level, Gender } \\
\text { of Primary School Child* }\end{array}$ & $\begin{array}{c}\text { Name, Grade Level, Gender } \\
\text { of 2nd Primary School } \\
\text { Child* }\end{array}$ \\
\hline Tricia & Weekly Volunteer & Hadley, 1st, female & Tyler, K, male \\
\hline Elizabeth & Philanthropy & Brigs, 3rd, male & Caroline, 2nd, female \\
\hline Kate & Playground Solunteer & Em, 3rd, female & Lola, 1st, female \\
\hline Genie Wilson & Playground Supervisor & Avery, 2nd, female & \\
\hline Mrs. Ludke & Slayground Supervisor & Aron, 3rd, female & \\
\hline Carlene Marks & 3rd grade teacher & Colt, 2nd, male & \\
\hline Winnie & 1st grade teacher & Brooklyn, 4th, female & Scott, K, male \\
\hline Erin & K teacher & Harper, K, female & \\
\hline Jessica & Volunteer & Ky, 4th, female & \\
\hline Maggie & Parent Volunteer & Milly, 3rd, female & Ellie, K, female \\
\hline Eden &
\end{tabular}

* Note, because children's social and emotional development is very personal, any identifying information, including the names of all parties involved in the study, and the name of the school and district, have been changed within this report. 


\section{Results}

After spending fifteen hours on the sun-soaked, shriekfilled, end-of-school-year playground, I was the only one kicking the dirt. I had witnessed only a handful of students use the bench. Almost all of the usage I witnessed occurred within the first few seconds of recess. Most children did not even sit before they were approached by flock of screaming students flying by whom they quickly joined. My hopes of recording thoughtful interludes, like "I've felt like that before too," felt completely dashed. However, as children's drawings, parent interviews, and observation field notes were collected, transcribed, and coded; themes related to the meanings of the buddy bench emerged. I realized it wasn't the bench's usage as much as its presence on the playground that communicated significant meanings carried by the children.

\section{The Bench's Debut and Inception}

To understand how these meanings were created, it is important to recognize the intentional delivery and anticipation with which the buddy bench was presented to the children and school community. Winnie Schultz, previously introduced as the school's most requested teacher and winner of the state's excellence in teaching award, is a self-proclaimed proponent of "character education, first and foremost." True to her driving mission, Winnie became the buddy bench champion and implementer. She said simply, "I made it happen" (personal communication, June 15, 2016). Which, upon further elaboration, reveals an entire process.

"First," Winnie said, the design of the bench needed to be "appealing and attractive. Kids need to feel like it's a special place to sit; not like you're on the sidelines for being lonely, like you are in the spotlight for being a potential friend" (personal communication, June 15, 2016). Winnie says, "If it's well done, they'll do it well."

Once designed, the bench was introduced to the children at the all-school "kindness carnival" assembly. The kidness carnival is an annual school event the children collectively earned throughout the month of February by committing individual acts of kindness. The purpose of the assembly was to explain to the students how to earn the carnival. Winnie's face lit up as she exclaimed, "Of course, the emblematic act of kindness we emphasized at the assembly this year was inclusivity! Cue the buddy bench!"(personal communication, June 15, 2016).

At the assembly the school mascot, Roaring Rex, a six-foot costumed lion donning a high school basketball jersey, introduced the buddy bench through a series of skits. In the first skit, Roaring Rex was sad on the playground and didn't know whom to play with until he spotted the bench and took a seat. Once seated, a group of teachers invited Rex to join them hopscotching. The crowd was encouraged to "Cheer for Rex, our hero who solved his problem by sitting on the buddy bench and finding new friends." In the next skit, a teacher moped across the stage saying, "Dang it! I don't have anyone to play with." Then, she said, "I guess l'll try out the buddy bench!" Pretty soon, Roaring Rex came to ask her to jump rope and the crowd was encouraged to "Cheer for Roaring Rex, our hero who invited someone sitting on the bench to play!" In the last skit, Roaring Rex took the bench, head in hands, shoulders shaking. A teacher said, "Hi Rex! Wanna Play?" Roaring Rex shook his head "no." The teacher said, "You seem pretty sad. Want to walk around and talk about it? Maybe once you feel better we can play?" Roaring Rex agreed. As the two walked, hand in hand, the narrator said, "Sometimes even Roaring Rex gets sad and needs a good friend." Then the narrator simply said:
We all get lonely sometimes, even on the playground. If you don't know who to play with, be like Roaring Rex and have a seat on the buddy bench. If you see someone sitting on the buddy bench, be like Roaring Rex and invite them to play.

The children cheered with Roaring Rex who then led them into the all school song about standing together and being the best in the West.

The bench officially "debuted" in late February at the Friday afternoon kindness carnival the children had successfully earned. Among booths where children bobbed for apples, did cakewalks, and discoed with the abandon only elementary school kids can exhibit, the bench was featured as "the photo booth." Children were encouraged to join, or round up a group of buddies (anyone), and use supplied props and costumes for a fun photo on the bench. Winnie explained that ensuring each child had a chance to sit on the bench and eliminate any fear about sitting on the bench before the bench was out on the playground was an important component to the bench's inception (personal communication, June 15, 2016). The buddy bench photos were posted in the school's entryway where children could see themselves and others happily sitting on the buddy bench. After the carnival, the bench went out to the playground blacktop where it remained for the rest of the year.

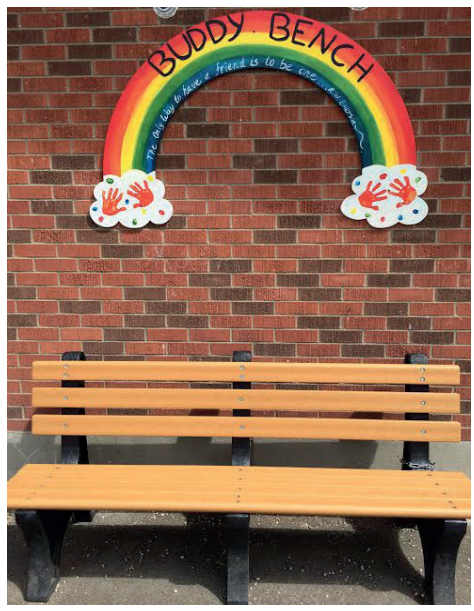

The buddy bench debuted on the playground after it had been introduced at the carnival.

RQ1: What is the socially constructed meaning of the playground buddy bench for children?

How would all this introductory fanfare translate to children's experiences on the playground? An overwhelming majority of the parents $\mid$ interviewed consider the playground both the most important, and the most challenging, aspect of their child's school day. One parent drives her children to Coeur D'Valle from out of district because Coeur D'Valle students get three recesses each day while the district her family lives in only offers one. Yet, she also lamented, "Our biggest challenges and most tumultuous times stem from recess."

Would the buddy bench help? Four months after its arrival, within my collection of interview transcripts, children's drawings, and observation notes, I found four dominant themes in children's meanings of the buddy bench: solidarity, worthiness, empowerment, and an overall shift in playground climate. These meanings changed children's narratives about themselves, others, and the playground experience for the better. 
RQ2: How, if at all, do the buddy bench meanings influence children on the playground?

Solidarity. Sweet second grader Avery stuck close by as her mother pulled Avery's folded drawing (Figure A) from her purse and our interview began. Without prompting Avery points to the drawing and says, "See, without the bench, I am the only person on the whole playground who gets lonely sometimes." She has drawn herself separate from the other children on the playground inside a box labeled "people who get lonely sometimes." Over her sad face, a bubble reads, "only me." Inside the box, Avery drew herself smaller than the other children on the playground. Within the picture of the playground without the buddy bench, Avery is the only child drawn in green while everyone else is in purple and placed within a dyad or triad of smiling children. "But," Avery continues as a proud smile spreads across her face, "With it (the buddy bench), I know everyone gets lonely sometimes. I feel better." In her drawing with the buddy bench, I see the box labeled "People who get lonely sometimes," has expanded to include everyone on the playground. And, in this illustration, even though not all the children are connected with others, they are all the smiling with more fleshed out bodies. Avery herself is bigger. In the drawing with the buddy bench, the children are all represented in different colors instead of being presented as a mass of purple children different from her. Before I can even give Avery a high five, she's run to join my daughters who are calling from the jungle gym, "Avery! Wanna be a unicorn or a mermaid?" Avery's mom, Genie, smiles as she watches her daughter join in play. She tells me that one night after reading bedtime stories Avery said, "Mom? You know that buddy bench? Maybe there are other kids at school who also don't have a BFF (best friend forever)." The buddy bench facilitated Avery's realization that she is not the only one at school who sometimes gets lonely or does not have a "BFF." This made her feel more similar, than dissimilar, to her peers.

Third grader Em's drawing (figure B) echoes Avery's perception of the buddy bench ameliorating the "I'm the only lonely one" concept of playground "insiders" and "outsiders." In Em's "without the buddy bench" drawing, she illustrated a lineup of children with three girls in the middle who are bigger, all dressed in black, and smiling. On the outside of the lineup, smaller children are frowning and have individual thought bubbles over their heads communicating, "I'm lonely" and "I'm the only one." This is juxtaposed against Em's "with the buddy bench" drawing where, like Avery's, all the children are in different colors, everyone is the same size, and everyone is smiling. In Em's "with the buddy bench" illustration, individual's "I'm the only one who gets lonely" ideas are replaced by a unifying rainbow encompassing all. We can see from these drawings that the buddy bench communicates to children that no one is an outsider. Em's mom expounds, "Before the buddy bench, if Em didn't know who to play with at recess she'd come home crying, saying she was the only kid on the whole playground who doesn't have someone to play with." Her mother continues, "The bench's very presence on the playground directly negates that assumption! It says, 'Hey! Everyone gets lonely sometimes. And, here's where you belong!" The buddy bench's meaning here normalizes an experience that feels, by definition, isolating. This creates a feeling of solidarity amongst the children on the playground.

This message was not lost on Maggie Grant's fourth grader, Ky, who came home from school "totally jazzed," announcing, "Mom! Mom! We got a buddy bench at school." After Ky explained to her mom how the bench works, she concluded, "Either they put it there just for me, and I'm that special; or other kids get lonely too!" Ky's mother shakes her head; "Recess and friends have always been a challenge for Ky." I was surprised to hear this. Ky is very bright and seems to always be at the center of activity. "Really?" I inquired. "To me it looks like she's got the world on a string." Maggie smiles, "That's just it. We all struggle. We just also all try to hide it."

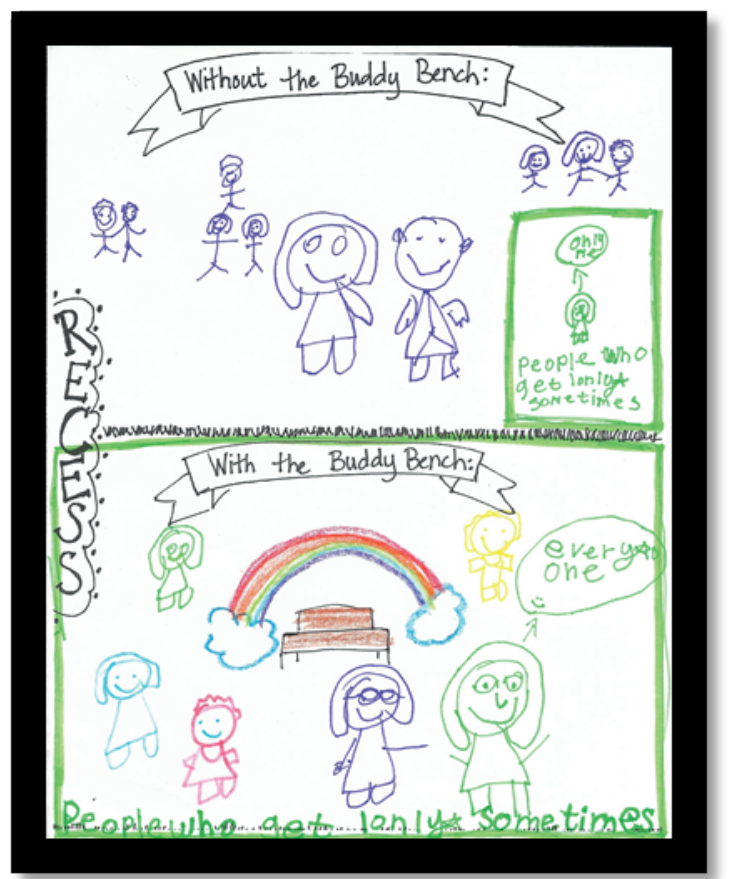

Fig A. Avery, Grade 2

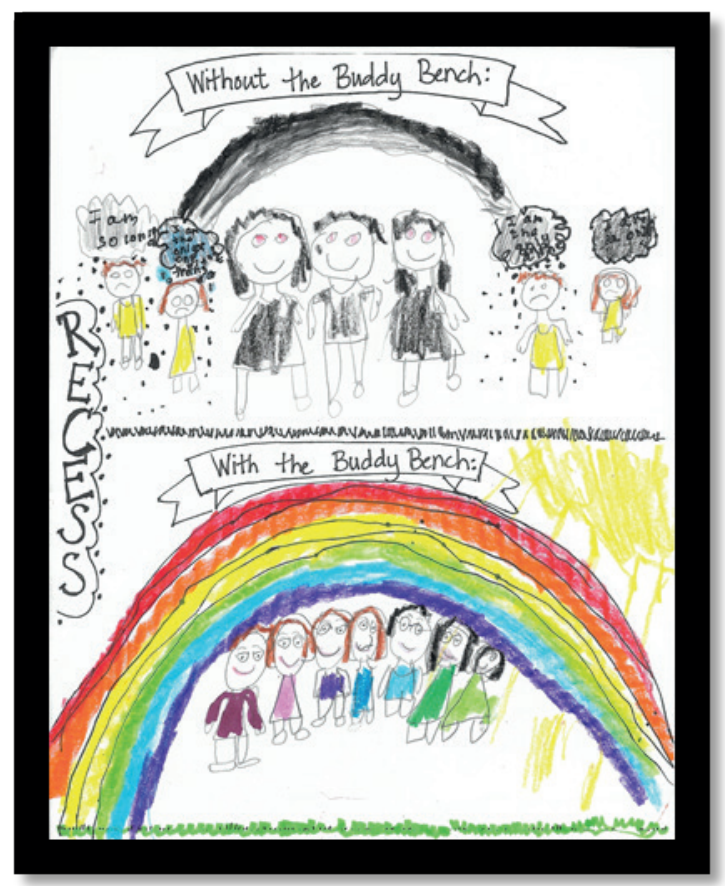

Fig $\boldsymbol{B}$. By Em, Grade 3

These children's drawings express that prior to the buddy bench these artists felt like being alone on the playground felt like a very isolating, or outsider experience. But, with the buddy bench there is a realization that everyone gets lonely sometimes and we are all in this together.

Worthiness. Children's artwork and parent interviews indicate that with the buddy bench communicating that everyone gets lonely sometimes, being alone on the 
playground is no longer cloaked in negativity and shame. With this altered perception, lone children can come out of hiding and are perceived as worthy of being seen and included.

Tricia was shocked to find out her first grade daughter Hadley even knew words like "Reject" and "Loser." Yet, in Hadley's "without the buddy bench" drawing (figure C), four stick figures frowning and facing sideways are on the playground sidelines under these labels along with, "No one Likes Me," and "How much longer?" Two girls, smiling, facing forward, and full-bodied announce from the middle of the playground, "We are friends." In Hadley's drawing with the bench, all the children on the playground are facing forward, smiling, full-bodied, and each child is uniformly labeled "Buddy" whether they are with a friend or not. Tricia is disappointed, "Is this how she viewed others?," she points to the before picture, "It kills me." Tricia continues, "At least now she sees everyone on the playground as equals. Everyone is worthy of playing and being included." I asked Tricia if Hadley had ever used the bench. "Hadley told me Harlow (a boy from her class) was on it the other day. She and a group of girls ran toward him, I'm sure he loved that! Before they could even get to him, he was running!" She laughs. "They all ended up playing tag."

Hadley wasn't the only student whose perception of children who didn't have a recess playmate was altered by the buddy bench. Kindergartener Harper is showing me her "without the buddy bench" drawing (figure D). She points to the figure looking sideways, "He's sad." She points to tears on the figure's face, "See?" She continues, "So, they don't want to play with him," she is pointing to the two figures smiling and holding hands. Harper's mom, kindergarten teacher, Jessica, is quick to move on to the more positive illustration, "What's going on here, Harper?" she asks pointing to Harper's "with the buddy bench" drawing. "Now they (the lonely child) can play," says Harper. In this drawing the rain and tears have been replaced by a rainbow that fills the page and encompasses all three children smiling, holding hands, and facing forward. The positions of the children have shifted so now the formerly "sad" person is in the middle of the other two.

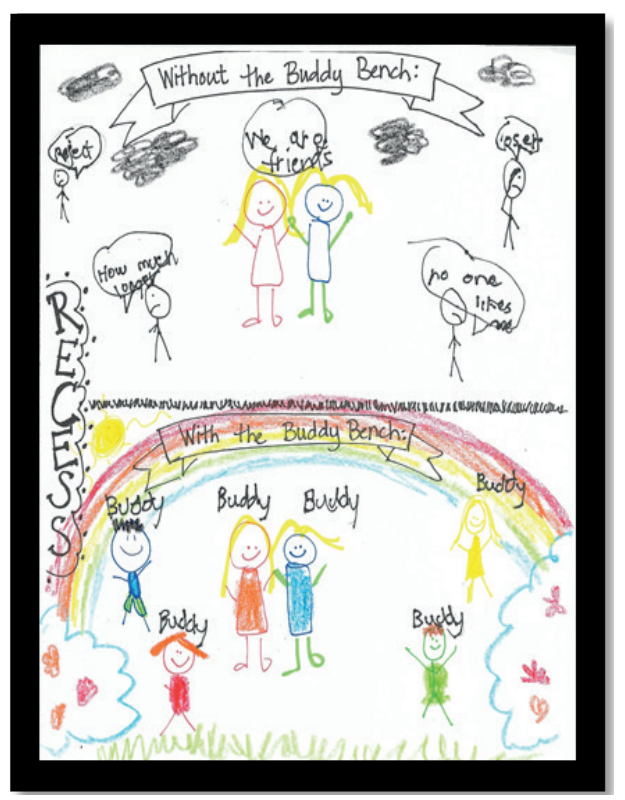

Fig C. By Hadley, Grade 1

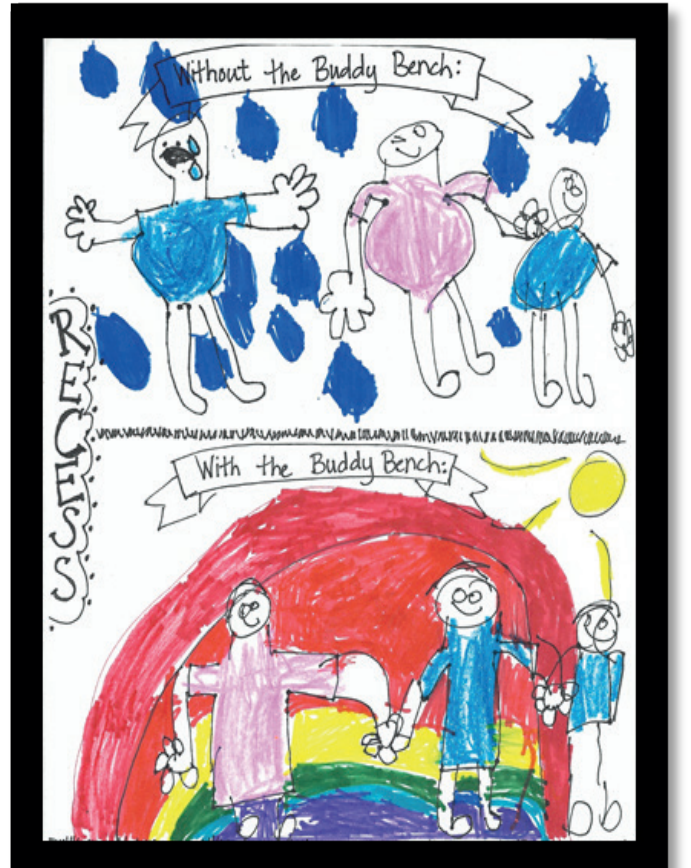

Fig D. By Harper, Kinder

These children's drawings express that prior to the buddy bench these artists felt like being alone on the playground was internalized as a feeling of worthlessness, but with the bench everyone is illustrated as deserving of a friend to play with.

Brooklyn, a fourth grader, captures the concept of the bench's presence transforming the shame of being without a playmate to a feeling of inherent worth (figure E). In Brooklyn's without the buddy bench drawing, "If you didn't know who to play with, you just wanted to disappear." She points to ghosts she drew hiding behind trees, under the slide, and around and inside the school building.

But, with the bench, "It's ok if you don't know what to do at recess. It's not embarrassing anymore." She points to the second drawing where the ghosts are now smiling children incorporated into play.

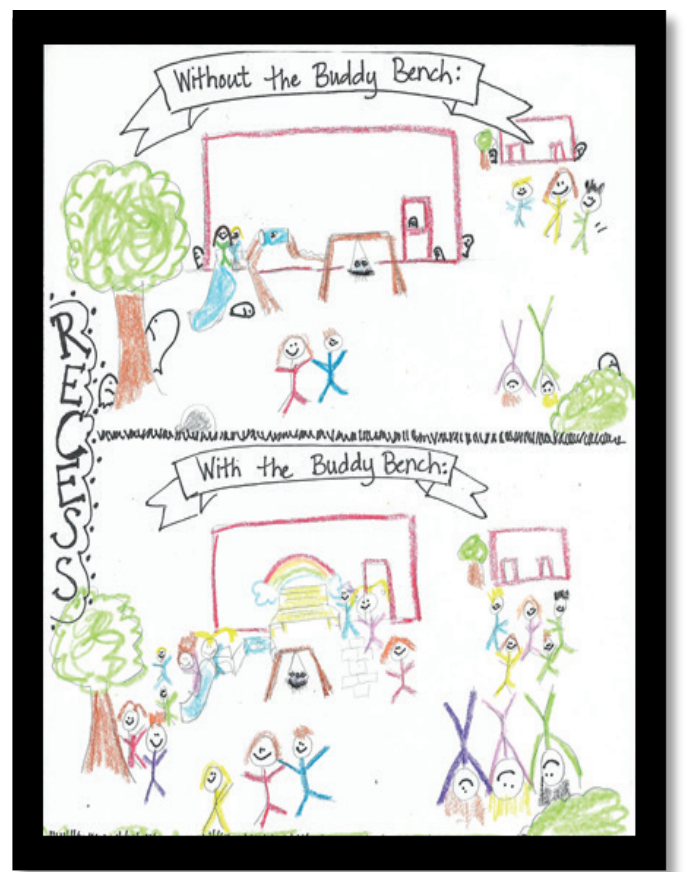

Fig E. Brooklyn, grade 4 


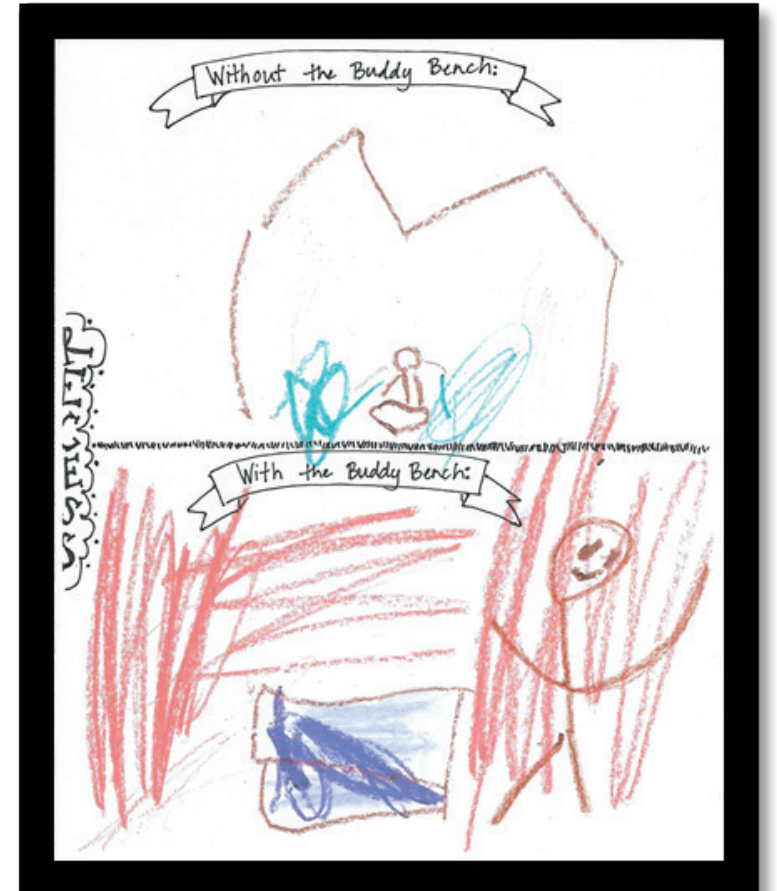

Fig $\boldsymbol{F}$. Tyler, Kinder

These children's drawings express that prior to the buddy bench being alone on the playground was shameful and made one hide on the playground or in the bathroom, but with the buddy bench you can openly show yourself on the playground and be ready to make a new friend.

Perhaps the most poignant buddy bench art piece comes from kindergartener Tyler. In his "without the buddy bench" drawing (figure F), "I hid in the bathroom." Here, he draws himself very small, his limbs cast down and curled under him. He lacks any facial expressions. But, with the buddy bench, "I can go outside," he beams, "I can make friends!" In his picture with the bench his figure fills the page and he is smiling, with arms open, as he stands next to the bench ready to receive a new friend. Kate tells me her daughter, $\mathrm{Em}$, also took to hiding in the bathroom when, as a new student in first grade at a different school Em, "couldn't stand the shame of wandering around the playground alone anymore." Kate reflects, that even three years after Em's recess in the bathroom days, the buddy bench allowed Em to reframe her experience from, "Everyone had someone to play with, so there was something wrong with me," to, "Anyone who is new to a school would need help finding new friends on the playground; that school needed a buddy bench." Em's story changed from, "I was a loser," to, "The school needed a buddy bench." The bench takes the personalization out of being lonely by making it about circumstance, not about who you are.

The children's perception of the buddy bench transforms the meaning of being alone on the playground from a shaming experience to an opportunity to meet new friends, and from wanting to hide to proudly being seen and incorporated into play. With the buddy bench on the playground children without a playmate are perceived by themselves, and others, as worthy of being seen and befriended.

Empowerment. While the buddy bench was presented as a solution for children who do not know who to play with, the interviews, drawings, and observations reveal another often even more utilized purpose in the buddy bench: children claiming ownership over their playground experience. Third grader Aron's mom Carlene says, "Oh, the buddy bench arrival was a banner day in Aron's life." Carlene says her third grader came home yelling, "Mom!
Mom! You're not going to believe this! You don't have to just play with just your best friends at recess anymore. You can play with ANYONE on the playground. ANYONE."

Carlene asked Aron what he meant, and all the gusto went out of him. He shook his head, "Mom. Buddy bench. Google it."

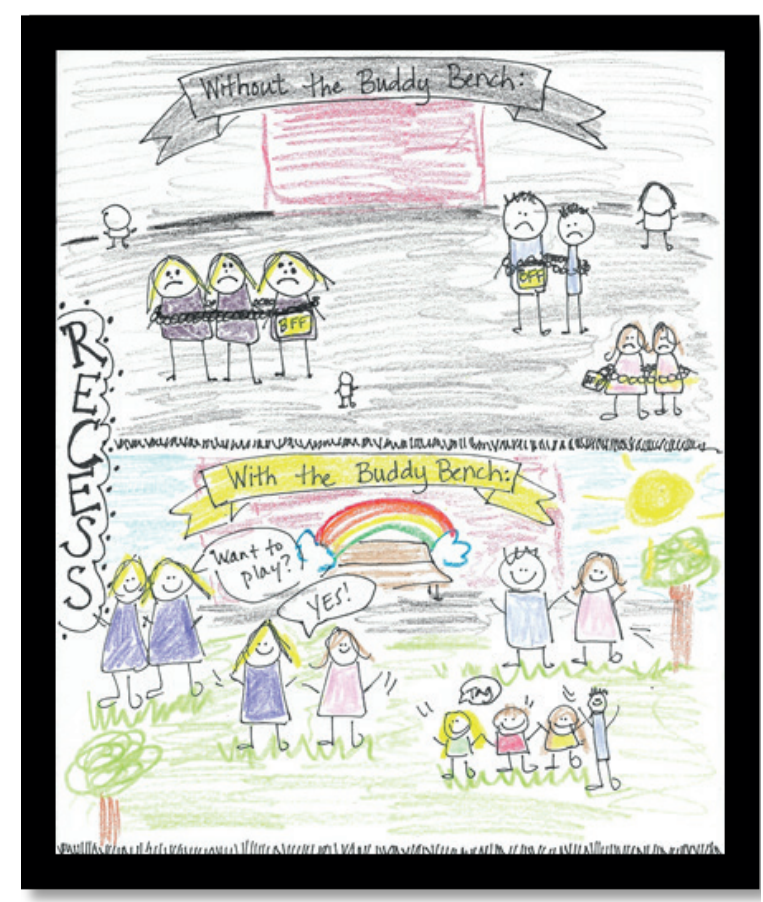

Fig $\mathbf{G}$. Ky, $4^{\text {th }}$ Grade

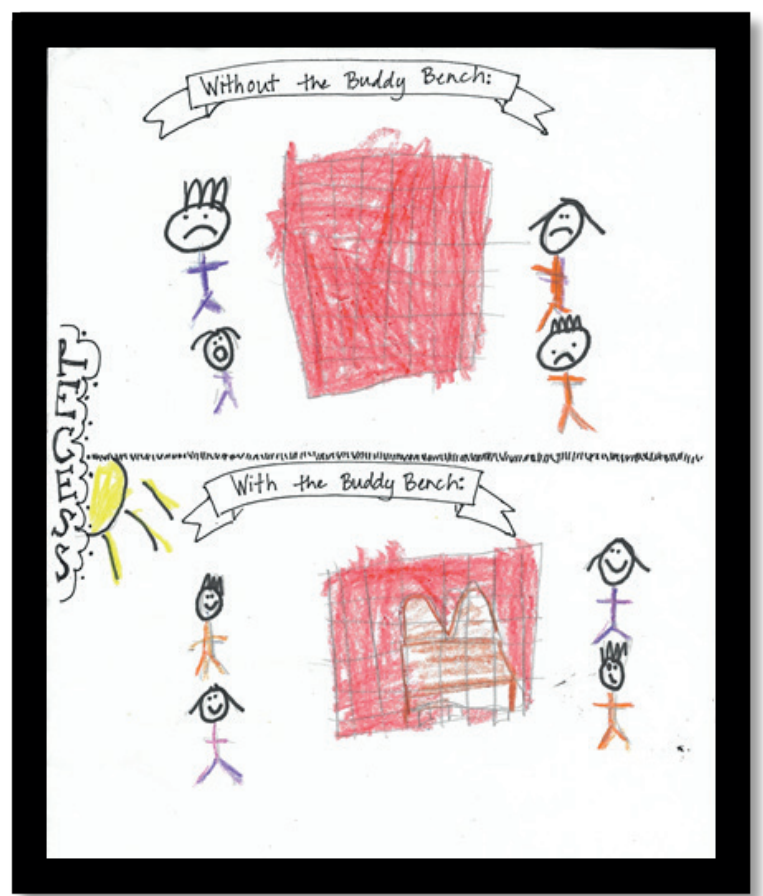

Fig $\boldsymbol{H}$. Aron, $3^{\text {rd }}$ grade

These children's drawings express that prior to the buddy bench these artists felt like they were stuck playing with the same friends at recess, even when it wasn't enjoyable. But, with the buddy bench, the artists feel empowered to leave less than satisfying interactions and mix up their playmates. This facilitates joyful and fluid interactions.

While children who don't know who to play with are invited 
to sit on the bench, children who aren't happy with who they are currently playing with and want to play with someone new or different, or who just want to try out the bench and see what happens are all welcome to use the buddy bench. In parent interviews, the bench was referred to as "a conduit," "a tool," "a reset," "a strategy," "a choice," "an option," and "self-directed social engineering."

All these labels indicate a choice granting children a tangible opportunity to own their playground experience. Most of the buddy bench stories shared involved a child who was not happy playing with their usual friends choosing to go sit on the bench and thus initiate play with others. Speaking about her fourth grader, Maggie says:

Ky has unrealistic expectations about friendship being total adoration and zero conflict. Where she used to get mired down in the chasm between her expectations and reality, and spend recess bickering with the same two girls, now she can just go sit on the bench and recalibrate with a new cast of characters.

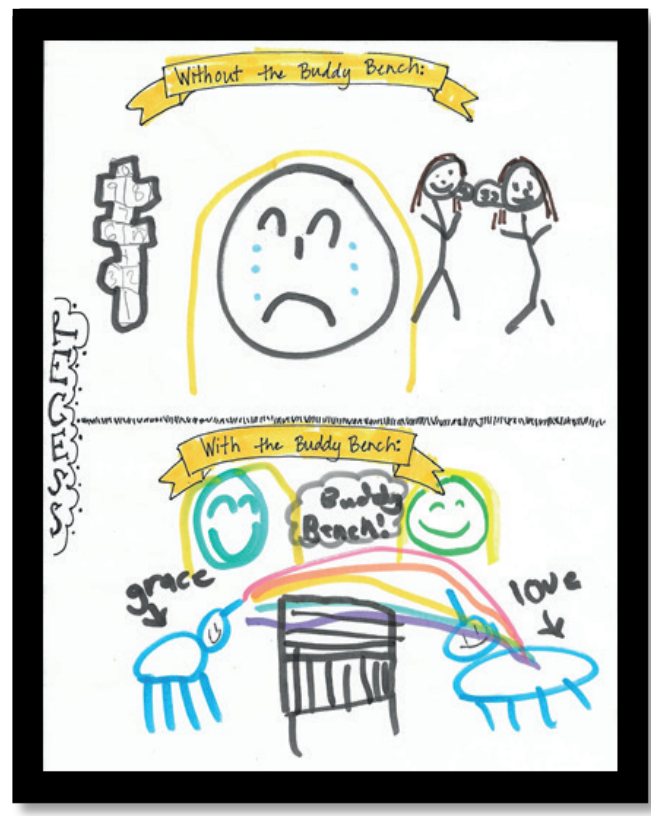

Fig I. Caroline, $2^{\text {nd }}$ grade

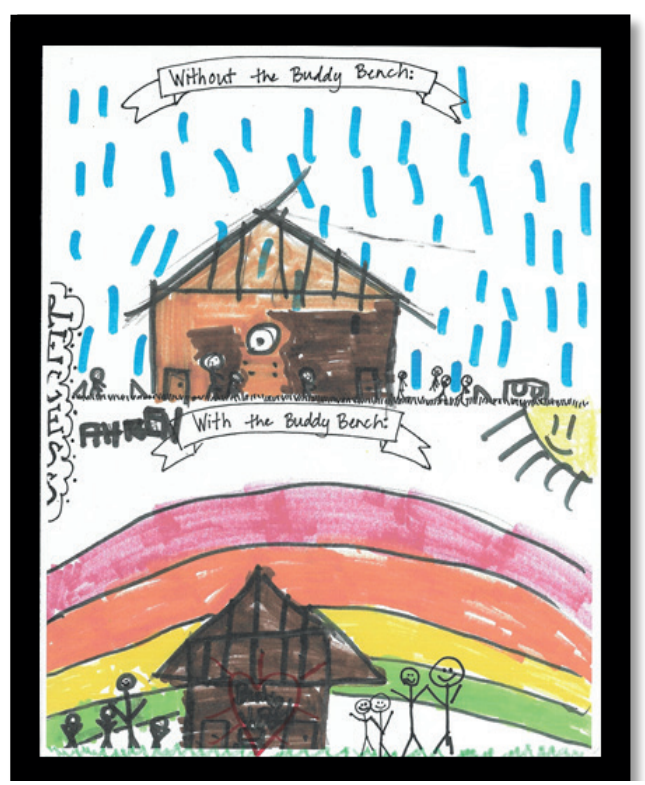

Fig J. Colt, $2^{\text {nd }}$ grade
These children's drawings express that prior to the buddy bench these artists have no recourse when they are ousted by friends, but with the buddy bench there is opportunity for selfempowerment in the face of rejection.

Trisha says her first grader Hadley, "Got so sick of (kids saying), 'If you don't do this, you aren't my best friend anymore.' With the buddy bench that statement loses all its bite. Because, hey, that's ok, l'll go sit on the bench and play with someone else."

Ky (figure $\mathrm{G}$ ) and Aron's (figure $\mathrm{H}$ ) drawings both speak to the buddy bench empowering children to play with someone new and this leading to a happier and more fluid playground expereince. These drawings show children going from being sadly stuck playing with their same best friends to happily playing with their existing best friends or someone new and different.

Does sitting on the bench work to reset a playground experience gone awry? My observations confirmed what playground supervisor Mrs. Ludke relays, "Kids usually don't sit on the bench more than a few seconds before they've either spotted something they want to join and hop off, or they get scooped up by another kid coming to sit on the bench."

The most negative feedback I received about the bench came from Maggie. Her fourth grader sat on the bench and no one came to get her:

She felt super dejected and was telling this pathetic sob story about how nobody came. "Nobody even cares about me. I'm such a reject. Blah, Blah, Blah!" But, when I asked her what she did about it, she said, "I saw a game of freeze tag while I was sitting there waiting. It looked kinda fun. So, I did that."

Maggie went on to say that she pointed out, "Well, isn't that good that you took responsibility for your own fun? Wasn't that better than fighting with the usuals?' Ky was all, 'I guess.' But, she was so obviously pleased with herself for solving her own problem.

Reiterating the theme of empowerment, Elizabeth relayed the story of her second grader Caroline's drawing (figure I). Caroline's usual recess playmates told her, "Go away. No one wants to play with you." Elizabeth said incidents like this had happened before and usually led to Caroline moping about for days and feeling sick before school. However, Elizabeth says, "Somehow, in that moment of sheer rejection, instead of curling up and crying, Caroline had the wherewithal to find her way to the buddy bench." Elizabeth smiles, "A little girl from her class immediately retrieved her. She said it felt like being saved by magical unicorns of grace and love." Elizabeth adds, "I am so proud of her for using that bench and not letting those girls define her or her playtime. That bench changed the trajectory of her story that day, and hopefully into the future."

Playground supervisors Mrs. Ludke and Mrs. Marks both mentioned some children like to play alone. Mrs. Ludke adds, the presence of the bench ensures their independent play is by choice and not by default. These meanings the children hold about the buddy bench allow for more playground fluidity and empower children with a tool that enables them to choose with whom to play.

\section{Changing Perspectives.}

By normalizing and universalizing loneliness; underlining individual's inherent worth; and empowering children by offering them choice and control over their playground experience, the buddy bench meanings changed the children's overall perspective of the playground climate. Lola's drawing (figure K) shows that with the buddy bench 
on the playground her approach to recess has changed from "lookout for boles" (bullies) to "look for budees" (buddies). Lola's shift in perspective is echoed in third grader Milly's drawing (figure L) where the buddy bench on the playground transforms children's thoughts from "Hope no one is mean to me," to "Who can I be nice to?" Playground supervisor Genie Wilson explains the shift in focus:

Before the buddy bench, playground lessons were all about bully proofing. How to spot a bully, how to stand up to one, how to assert yourself, how you deserve to be treated... it's like we were arming our children to be attacked. Now, they're headed out to the playground looking for buddies instead of bullies. Rather than worrying about how they're going to get hurt by others, they're looking for how they can help others. It's a completely different outcome. What we feed, we foster.

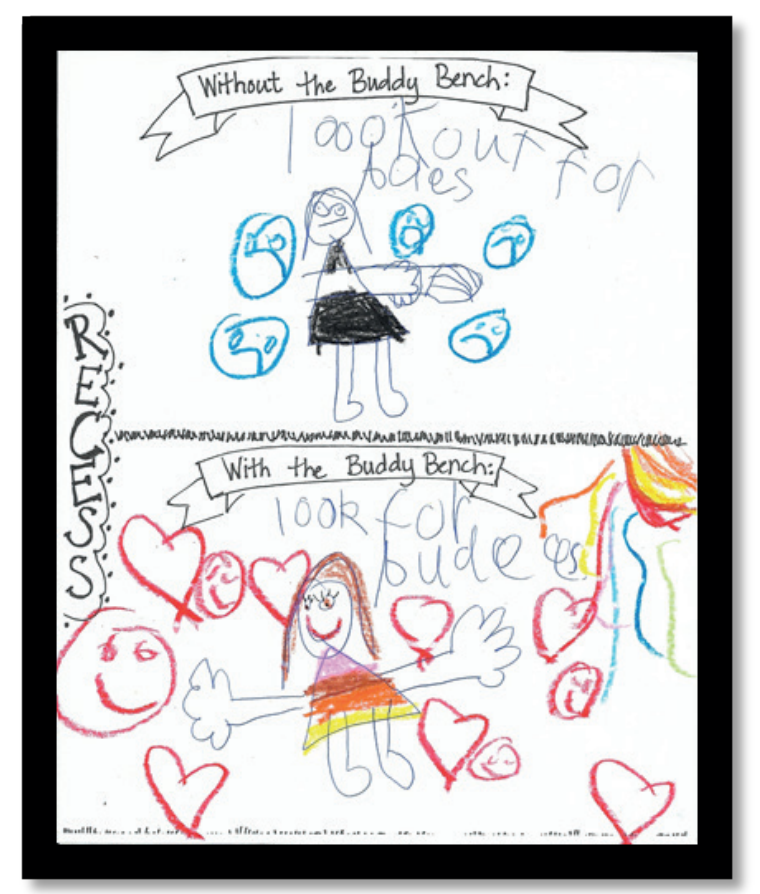

Fig $\boldsymbol{K}$. Lola, $1^{\text {st }}$ grade

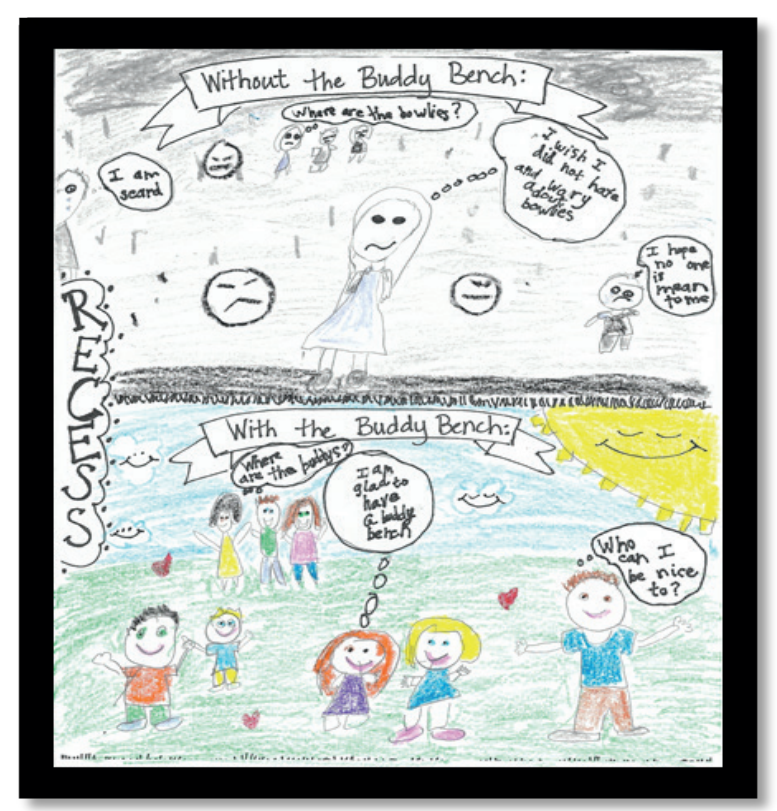

Fig L. Milly, $3^{\text {rd }}$ Grade
These children's drawings express that with the buddy bench the artists perceive an overall climate shift on the playground as children change their overall playground approach from "look for bullies," to "look for buddies."

Fourth grade parent Maggie says, "The overriding message is stop thinking of yourself, start thinking about others. Whenever we are dealing with recess drama I tell Ky, 'The best way to get happy is to make someone else happy,' the buddy bench gives her a chance to practice that." Elizabeth's sentiments echo Maggie's:

I don't care what the report card says, or what the standardized test scores indicate about my children's abilities to memorize and spit back facts. Computers can do all that stuff better than we'll ever be able to anyway. Only people can make our other people's lives better. That's a critical skill that deserves practice. That's what the buddy bench is for.

Like Elizabeth, most of the parents I interviewed stated that while reading and math skills are important, they hope their children learn to better understand and get along with others while they are at school. They value building empathy and kindness. The buddy bench ushering a shift in focus from self to others demonstrates that the buddy bench provides an opportunity for children to practice being considerate, inclusive, and thoughtful.

Together these meanings: solidarity, worthiness, empowerment, and a shift from thinking about yourself and being bullied to thinking about others and being a buddy caused an overall shift in playground climate. This is evidenced by the collection of children's drawings where gray, rainy skies and frowns transform to sunshine, rainbows, and smiles with the presence of the buddy bench and the meanings it imparts.

\section{Discussion}

In social construction semiotic terms, the meaning of the sign, the bench, exists within the children's interpretations of it. Analysis of drawings, interviews, and observations identified shared meanings the children hold related to the buddy bench: solidarity, worthiness, empowerment, and an opportunity to practice kindness. Because social construction theory posits that knowledge and meanings are constantly evolving and a product of individual perceptions based on societal, group, and cultural experiences within an individual's field of experience (Berger \& Luckmann, 1966), follow up studies would indicate how the children's socially constructed meanings evolve over time.

According to McAdams and Guo's narrative identity theory, the shift in the children's narratives based on the meanings they attributed to the buddy bench demonstrate how the children's perception of the buddy bench influenced their understandings of themselves, others, and the playground experience. These changes in narratives illustrate that children's personal narrative identities have been reshaped. We see that the narrative of the lonely child on the playground shifted from feeling ashamed and hiding, to feeling worthy of being seen and included. We also can see that children's perception of lonely children transformed from "reject" to "buddy." The buddy bench also changed the children's playground narrative from, "I have to play with my standard playmates, no matter how they treat me," to, "I can choose who I play with." These empowering narratives strengthened children's locus of control. They also speak to the themes of growth, communion, and agency that McAdams and Guo identified as narrative elements present in redemptive narrative stories, which build positive identities. McAdams and Guo's finding that redemptive narrative stories like the ones the children on the playground are now telling, are indicative 
of the storyteller's feelings of purpose and correlate with future prosocial behaviors. This underlines the worth of playground buddy benches in elementary school settings.

This study contributes to the communication field by offering an application of children's art interpretation, a methodology typically used in psychology and psychiatry as a clinical diagnostic tool, as a means of identifying children's meanings directly from children. This methodology can be utilized by communication scholars engaged in future studies aimed at identifying and understanding children's meanings. It is a particularly relevant method of understanding meanings in the field of social construction where meaning is dynamic, evolving, and resides within the subject. This study proved analysis of children's artwork contextualized within interviews and observation provided children a way to express their experiences in a natural way, outside of a clinical practice setting where this method is typically employed. This study demonstrates that communication scholars can augment their methodology tool boxes by offering children this alternative way to share their perceptions.

\section{Limitations and Future Studies}

A prior study identifying the effects of the buddy bench in urban schools found most students had positive attitudes toward the buddy bench. However, the study called for more studies examining the effects of the buddy bench in different kinds of environments and also called for studies collecting direct observations (Griffin et. al, 2017, p. 34). This study answered those calls, but there is still much room for future research. This study was limited in that it explored the buddy bench effects looking at the broad population of all children grades kindergarten through fourth grade. Exploring the effects of the bench in specific populations, such as by grade level or by student groups with specific or individual needs could add additional insight. Examining the influence, and synergistic effects, of using the buddy bench along with other social emotional and play enhancing interventions, including ones at home, could also enrich our understandings.

\section{Conclusion}

This amalgam of interpretations identifies the buddy bench's socially constructed meanings amongst children on the playground. Through the children's stories, as told through observation and their artwork, we see how these shared meanings are influencing the children's narrative identity formation. The buddy bench's presence has fostered empowering narratives with emphasis on community, agency, and growth and this leads to positive identity formation and cultivating contributing citizens who view their lives as meaningful. The method of identifying these meanings through the analysis of children's artwork contextualized within in-depth parent-child interviews, faculty and staff interviews, and playground observations provides researchers with an example of a viable method of better understanding children's meanings directly from them and in their natural settings.

While the buddy bench alone is not a panacea or a conduit for world peace, perhaps like the primary school playground, the world would look different if humankind held shared meanings of solidarity, inherent worth, personal empowerment, and a shift in perspective from looking for how one can be wronged, to looking for how one can help. These are the lessons, and the meanings, of the buddy bench. As the buddy bench program, and programs like it are implemented on playgrounds and in schools across the nation, perhaps future generations will be empowered to change not just the playground climate, but also our society's.

\section{References}

Adler, J. M., Turner, A. F., Brookshier, K. M., Monahan, C., Walder-Biesanz, I., Harmeling, L. H., \& Oltmanns, T. F. (2015). Variation in narrative identity is associated with trajectories of mental health over several years. Journal of personality and social psychology, 108(3), 476.

Akmeşe, P. P. \& Kayhan, N. (2017). An investigation of the self-efficacy levels of the special education teachers regarding game teaching. Special education magazine, 18(1), 1-26.

Arthur, L. (2004). Looking out for each other: Children helping left $\square o u t$ children. Support for Learning, 19(1), 5-12.

Ashiabi, G. S. (2007). Play in the preschool classroom: Its socio-emotional significance and the teacher's role in play. Early Childhood Education Journal, 35(2), 199-207.

Barthes, R. (1964). Elements of semiology. New York: HILL and WANG.

Batu, B. (2012). An Overview of the Field of Semiotics. Procedia-Social and Behavioral Sciences, 51, 464-469.

Barros, R. M., Silver, E. J., \& Stein, R. E. (2009). School recess and group classroom behavior. Pediatrics, 123(2), 431-436.

Berger, P. \& Luckmann, T. (1966). The social construction of knowledge: A treatise in the sociology of knowledge. NY: Doubleday.

Blasi, M., Hurwitz, S. C., \& Hurwitz, S. C. (2002). For Parents Particularly: To Be Successful-Let Them Play! Childhood Education, 79(2), 101-102.

Botev, A., \& Dimov, E. (2018). Christian's Buddy Bench. Retrieved September 9, 2018, from http:// buddybench.org/

Bowen, G. A. (2008). Naturalistic inquiry and the saturation concept: a research note. Qualitative research, 8(1), 137-152.

Brown, S. L. (2009). Play: How it shapes the brain, opens the imagination, and invigorates the soul. Penguin.

Byers, J. A. (1998). The biology of human play. Child Development, 69(3), 599-600.

Ginsburg, K. R. (2007). The importance of play in promoting healthy child development and maintaining strong parent-child bonds. Pediatrics, 119(1), 182-191.

Grant, A., \& Dutton, J. (2012). Beneficiary or benefactor: Are people more prosocial when they reflect on receiving or giving? Psychological science, 23(9), 1033-1039.

Griffin Jr, A. A., Caldarella, P., Sabey, C. V., \& Heath, M. A. (2017). The effects of a buddy bench on elementary students' solitary behavior during recess. International Electronic Journal of Elementary Education, 10(1), 27-36.

Jacob, E. (1987). Qualitative research traditions: A review. Review of educational research, 57(1), 1-50.

Jarrett, O. S., Maxwell, D. M., Dickerson, C., Hoge, P., 
Davies, G., \& Yetley, A. (1998). Impact of recess on classroom behavior: group effects and individual differences. The Journal of educational research, 92(2), 121-126.

Kamenetz, A. (2016, July 5). How To Raise Brilliant Children, According To Science. Retrieved July 10, 2016, from http://www.npr.org/sections/ ed/2016/07/05/481582529/how-to-raise-brilliantchildren-according-to-science

Koçan, N. (2012). A study on the competence of children's playgrounds: An example of Uşak City Kemaloz District. Erciyes University Journal of the Institute of Science and Technology, 28(4), 315-321.

Merriam, S. B. (1988). Case study research in education: $A$ qualitative approach. Jossey-Bass.

McAdams, D. P., \& Guo, J. (2015). Narrating the generative life. Psychological Science, 26(4), 475-483. doi:10.1177/0956797614568318

McAdams, D. P., Reynolds, J., Lewis, M., Patten, A. H., \& Bowman, P. J. (2001). When bad things turn good and good things turn bad: Sequences of redemption and contamination in life narrative and their relation to psychosocial adaptation in midlife adults and in students. Personality and Social Psychology Bulletin, 27(4), 474-485. doi:10.1177/0146167201274008

McNiff, S. (1976). Art, artists and psychotherapy: A conversation with Robert Coles. Art Psychotherapy, 3(3), 115-133.

O'Connell, P. M. (2013, January). Give Them A Break; AAP policy touts physical, mental, social benefits of recess. AAP News, 34(1). Retrieved July 12, 2016, from http://aapnews.aapnewspublications.org/ content/34/1/7.1.

Oster, G. D., \& Crone, P. G. (2004). Using drawings in assessment and therapy: A guide for mental health professionals. Psychology Press.

Panksepp, J. (2007). Can PLAY diminish ADHD and facilitate the construction of the social brain?. Journal of the Canadian Academy of Child and Adolescent Psychiatry, 16(2), 57.

Peirce. C. P. (1965). Basic Concepts of Peircean Sign Theory. In Gottdiener, M., Boklund-Lagopoulou, K. \& Lagopoulos, A.P. (Eds.) (2003). Semiotics. London: Sage Publications.

Pellegrini, A. D. (2008). The Recess Debate: A Disjuncture between Educational Policy and Scientific Research. American Journal of Play, 1(2), 181-191.

Pellegrini, A. D., Blatchford, P., Kato, K., \& Baines, E. (2004). A ShortDterm Longitudinal Study of Children's Playground Games in Primary School: Implications for Adjustment to School and Social Adjustment in the USA and the UK. Social Development, 13(1), 107123.

Pellegrini, A. D., \& Bohn, C. M. (2005). The role of recess in children's cognitive performance and school adjustment. Educational Researcher, 34(1), 13-19.

Pellegrini, A. D., \& Galda, L. (1993). Ten years after: A reexamination of symbolic play and literacy research. Reading Research Quarterly, 163-175.
Pellegrini, A. D., Huberty, P. D., \& Jones, I. (1995). The effects of recess timing on children's playground and classroom behaviors. American Educational Research Journal, 32(4), 845-864.

Pellegrini, A. D., \& Long, J. D. (2002). A longitudinal study of bullying, dominance, and victimization during the transition from primary school through secondary school. British journal of developmental psychology, 20(2), 259-280.

Ramstetter, C. L., Murray, R., \& Garner, A. S. (2010). The crucial role of recess in schools. Journal of School Health, 80(11), 517-526.

Reed, J. A., Einstein, G., Hahn, E., Hooker, S. P., Gross, V. P., \& Kravitz, J. (2010). Examining the impact of integrating physical activity on fluid intelligence and academic performance in an elementary school setting: a preliminary investigation. Journal of physical activity \& health, 7(3), 343.

Rönnlund, M.(2015). Schoolyard stories:Processes ofgender identity in a 'children's place'. Childhood, 22(1), 85100.

Rosenthal, R., \&. Jacobson, L. (1963). Teachers' expectancies: Determinants of pupils' IQ gains. Psychological Reports, 19, 115-118.

Scarlett, H. H., Press, A. N., \& Crockett, W. H. (1971). Children's descriptions of peers: A Wernerian developmental analysis. Child development, 439453.

Skelton, C., \& Francis, B. (2003). Boys and girls in the primary classroom. McGraw-Hill Education (UK).

Stellino, M. B., \& Sinclair, C. D. (2008). Intrinsically motivated, free-time physical activity: considerations for recess. Journal of Physical Education, Recreation \& Dance, 79(4), 37-40.

Thompson, M., O'Neill, \& Cohen, L. J. (2001). Best friends, worst enemies: Understanding the social lives of children. Random House Digital, Inc.

Werner, H. (1967). The concept of development from a comparative and organismic point of view. ( $\mathrm{N}$ - New ed., pp. 125) University of Minnesota Press.

Wolke, D., Woods, S., Stanford, K., \& Schulz, H. (2001). Bullying and victimization of primary school children in England and Germany: Prevalence and school factors. British Journal of Psychology, 92(4), 673-696.

Yin, R. K. (2003). Case study research design and methods third edition. Applied social research methods series, p. 5. 


\section{Appendix}

\section{Faculty / Staff Interview Guide}

1. How did the buddy bench come about at this school?

2. How was it introduced to the children?

3. How would you say reception has been?

4. How has the buddy bench helped / hurt the children? The playground / school culture?

5. Do you have any success stories? Any failure stories?

6. What do you think the bench means to the children?

7. What (if any) are the learning outcomes of the buddy bench?

8. Anything else you'd like to mention about recess, school culture, or the buddy bench?

\section{Parent Interview Guide}

1. How did you first hear about the buddy bench at school?

2. How would you explain what the buddy bench is?

3. How would you describe your child?

4. How would you describe your child's attitude and behavior at school? At recess?

5. Has your child ever told you a story about the buddy bench?

6. In what ways has the buddy bench helped / hurt your child?

7. What do you think the buddy bench means to the children?

8. Anything else you'd like to mention about recess, your child, school culture, or the buddy bench?

\section{Art Prompt for Children}

1. Draw a picture of the playground without the buddy bench.

2. Draw a picture of the playground with the buddy bench.

3. Tell me about your drawings. 
This page is intentionally left blank www.iejee.com 